\title{
EFEITO DA AZADIRACTINA SOBRE Chaetosiphon fragaefolli (COCKERELL, 1901) (HEMIPTERA: APHIDIDAE) NA CULTURA DO MORANGUEIRO ${ }^{1}$
}

\author{
DANIEL BERNARDI ${ }^{2}$, MAURO SILVEIRA GARCIA ${ }^{3}$, MARCOS BOTTON $^{4}$, \\ UEMERSON SILVA DA CUNHA ${ }^{5}$
}

RESUMO - O pulgão-verde Chaetosiphon fragaefolli é o principal inseto-praga da cultura do morangueiro. Neste trabalho, foi avaliado o efeito da azadiractina para o controle do inseto em laboratório e casa de vegetação. Os tratamentos avaliados foram a azadiractina $\left(\right.$ Azamax $^{\circledR}, 100 ; 200$ e $300 \mathrm{ml}^{\circledR} 100 \mathrm{~L}^{-1}$ ) comparado com o tiametoxam (Actara $250 \mathrm{WG}^{\circledR}, 10 \mathrm{~g} .100 \mathrm{~L}^{-1}$ ), lambda-cialotrina (Karate Zeon $50 \mathrm{CS}^{\circledR}, 80 \mathrm{ml}^{1} 100 \mathrm{~L}^{-1}$ ) e uma testemunha (água). Os produtos foram pulverizados sobre plantas de morangueiro da cultivar Aromas infestadas artificialmente em casa de vegetação. A azadiractina foi equivalente a lambda-cialotrina e ao tiametoxam no controle de $C$. fragaefolii desde que realizada uma segunda pulverização sete dias após a primeira. A persistência biológica dos inseticidas lambda-cialotrina e tiametoxam foi superior a 28 dias, com um controle de $75 \%$ da população de pulgões, enquanto azadiractina apresentou menor persistência biológica, controlando $70 \%$ da população por sete dias.

termos para indexação: Azadiractha indica, nim, pulgão-verde-do-morangueiro.

\section{EFFECTS OF AZADIRACHTIN ON Chaetosiphon fragaefolli (COCKERELL, 1901) (HEMIPTERA: APHIDIDAE) IN STRAWBERRY CULTURE}

\begin{abstract}
The greenbug Chaetosiphon fragaefolli is the main insect pest of strawberry. This study evaluated the effect of azadirachtin for the control of the insect in the laboratory and in the greenhouse. The treatments were azadirachtin $\left(\right.$ Azamax $^{\circledR} 100,200$ and $300 \mathrm{ml}^{100 \mathrm{~L}^{-1}}$ ), compared with thiamethoxam (Actara

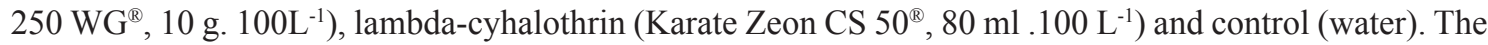
insecticides products were sprayed on strawberry plants infested artificially in the greenhouse. Azadirachtin was equivalent to lambda-cyhalothrin and thiamethoxam to control $C$. fragaefolli since a second spray is made seven days after the first. The biological persistence of the insecticides lambda-cyhalothrin and thiamethoxam was more than 28 days with a control of $75 \%$ of the population of aphids while azadirachtin was less persistent controlling $70 \%$ of the population for seven days.
\end{abstract}

Index terms: Azadiractha indica, nim, greenbug.

\section{INTRODUÇÃO}

O pulgão-verde Chaetosiphon fragaefolli (Cockerell, 1901) (Hemiptera: Aphididae) é o principal afídeo associado à cultura do morangueiro em diversos países, tais como Estados Unidos, Canadá, Argentina, Grã-Bretanha, África do Sul, Nova Zelândia e Austrália (RONDON;CANTCLIFFE, 2004; CÉDOLA; GRECO, 2010). No Brasil, a espécie é relatada como o principal inseto-praga da cultura (COSTA et al., 1993; BOTTON et al., 2010). O afí- deo apresenta hábito gregário, formando colônias na face abaxial das folhas mais novas, o que dificulta o controle, sobretudo quando são aplicados inseticidas de contato (SALLES, 2005), necessitando de uma a duas pulverizações de inseticidas por safra para o controle da praga.

Os principais prejuízos causados por $C$. fragaefolli na cultura do morangueiro são decorrentes da sucção de seiva que reduz o desenvolvimento das mudas e, consequentemente, da produção. Nas plantas infestadas, observa-se o surgimento de fu-

\footnotetext{
'(Trabalho 083-11). Recebido em: 07-03-2011. Aceito para publicação em: 04-01-2012.

${ }^{2}$ Eng. Agr., Doutorando do Depto. de Entomologia e Acarologia, ESALQ/USP, Av. Pádua Dias, 11, CEP: 13418-900, Piracicaba-SP. dbernardi2004@yahoo.com.br

${ }^{3}$ Eng. Agr., Doutor em Entomologia, Professor do Departamento de Fitossanidade, Faculdade de Agronomia Eliseu Maciel, Universidade Federal de Pelotas, Caixa Postal 354, CEP: 96010-900, Pelotas-RS. E-mail: garciasmauro@yahoo.com.br

${ }^{4}$ Eng. Agr., Doutor em Entomologia, Pesquisador da Embrapa Uva e Vinho, Rua Livramento 515, Caixa Postal 130, 95700-00, Bento Gonçalves-RS, marcos@enpuv.embrapa.br

${ }^{5}$ Eng. Agr., Doutor em Entomologia, Professor do Departamento de Fitossanidade, Faculdade de Agronomia Eliseu Maciel, Universidade Federal de Pelotas, Caixa Postal 354, CEP: 96010-900, Pelota-RS. E-mail: uscunha@ufpel.edu.br
} 
magina que reduz significativamente a qualidade do produto final. A espécie também é responsável pela transmissão de diversos vírus, principalmente o Vírus-da-faixa-das-nervuras-do-morangueiro (Strawberry vein banding virus, SVBV), Vírus-daclorose-marginal-do-morangueiro (Strawberry mild yellow edge virus, SMYEV), Vírus-do-encrespamento-do-morangueiro (Strawberry crinkle virus, SCV) e Vírus-do-mosqueado-do-morangueiro (Strawberry mottle virus, SMoV) (MELLOW; FRAZIER, 1970; CÉDOLA; GRECO, 2011).

O controle de C. fragaefolli tem sido realizado basicamente com o emprego dos inseticidas tiametoxam (neonicotinóide) e lambda-cialotrina (piretroide) (BOTTON et al., 2010; AGROFIT, 2011). No entanto, a aplicação destes inseticidas resulta em efeitos secundários indesejáveis, pois os mesmos afetam negativamente os ácaros predadores Neoseiulus californicus (MCGREGOR, 1954) e Phytoseiulus macropilis (BANKS, 1904) (Acari: Phytoseiidae), resultando em incrementos populacionais do ácaro-rajado Tetranychus urticae Koch, 1836 (Acari: Tetranychidae) considerado a principal praga da cultura no Brasil (POLETTI et al., 2008).

O emprego de extratos de plantas, principalmente da família Meliaceae com destaque para o nim (Azadirachta indica A. Juss), é uma alternativa para o manejo de pulgões na cultura do morangueiro (SANTOS et al., 2004; VENZON et al., 2007; BERNARDI et al., 2010). Produtos derivados do nim têm a vantagem de apresentar baixa toxicidade a animais de sangue quente e serem rapidamente degradados no solo e nas plantas, e não apresentar período de carência (ISMAN, 2006). Além disso, o nim afeta o comportamento, o desenvolvimento e a reprodução das espécies-alvo, principalmente através da ingestão (SCHMUTTERER, 1990; MARTINEZ, 2002).

Dentre os ingredientes ativos com propriedade inseticida presentes na planta de nim, destaca-se a azadiractina, um tetranortriterpenoide ativo no controle de diversas pragas (MARTÍNEZ, 2002). Em 2009, foi introduzido no mercado brasileiro uma formulação comercial derivada da planta de nim à base de azadiractina $\left(\right.$ Azamax $^{\circledR}$ ), sendo o único produto registrado no Ministério da Agricultura, Pecuária e Abastecimento (MAPA) para o controle de pragas na agricultura (AGROFIT, 2011). A formulação é autorizada para uso na cultura do morangueiro para o controle do ácaro-rajado T. urticae, sendo certificada pelo Instituto Biodinâmico (IBD) para emprego em sistemas de produção orgânica.

Devido ao manejo de pulgões na cultura do morangueiro ser realizado basicamente através da pulverização de inseticidas sintéticos, este trabalho objetivou avaliar a eficiência de controle e a persistência biológica de uma formulação comercial à base de azadiractina (Azamax ${ }^{\circledR}, 12 \mathrm{~g}$ de ingrediente ativo/ Litro) para o controle de C. fragaefolli.

\section{MATERIAL E MÉTODOS}

Os experimentos foram conduzidos em câmara climatizada do tipo BOD (temperatura de $25 \pm$ $1{ }^{\circ} \mathrm{C}$, umidade relativa do ar de $70 \pm 10 \%$ e fotofase de 12 horas) e em casa de vegetação da Embrapa Uva e Vinho, Bento Gonçalves-RS.

\section{Criação-estoque de $\boldsymbol{C}$. fragaefolli}

Adultos e ninfas de C. fragaefolli foram coletados em outubro de 2009 sobre folhas de morangueiros da cultivar Aromas, conduzidos no sistema de 'túnel baixo', localizado no município de Bom Princípio-RS, Brasil (29 04.31'06”S; $51^{\circ} 22$ ‘40”O e $68 \mathrm{~m}$ de altitude). Os pulgões foram multiplicados em plantas de morangueiro da cultivar Festival, cultivadas em vasos de polietileno $(3 \mathrm{~L})$ contendo solo, substrato industrializado $\left(\right.$ Plantmax $\left.^{\circledR}\right)$ e matéria orgânica na proporção $2: 1: 1$. Os vasos foram mantidos no interior de uma gaiola $(2 \mathrm{~m} \times 2 \mathrm{~m} \times 2 \mathrm{~m})$, revestida com tela antiafídeo $(0,64 \mathrm{~mm} \times 0,20 \mathrm{~mm})$. O substrato dos vasos foi irrigado a cada três dias, e os pulgões, transferidos a cada 20 dias para plantas novas da mesma cultivar.

\section{Efeito da azadiractina sobre $\boldsymbol{C}$. fragaefolli}

Para a realização do bioensaio, mudas de morangueiro da cultivar Aromas foram individualmente cultivadas em vasos de polietileno (3L), contendo solo, substrato vegetal e matéria orgânica $(2: 1: 1)$, no interior de casa de vegetação. Os insetos utilizados nos experimentos foram provenientes da criação-estoque.

Para a infestação das plantas, foi retirado um folíolo de morangueiro com aproximadamente 50 pulgões (ninfas e adultos) provenientes da criaçãoestoque, os quais foram colocados sobre as folhas mais novas da planta a ser infestada. Após três dias da infestação (fase abaxial e adaxial da folha), uma folha de morangueiro com pulgões foi marcada na região do pecíolo, por meio de uma tira de tecido branco umedecida com vaselina para evitar a fuga dos insetos quando da pulverização dos inseticidas e avaliação do experimento. Diariamente, verificou-se o ressecamento da vaselina e, quando necessário, a mesma foi reposta com auxílio de um pincel.

Avaliou-se a azadiractina $\left(\right.$ Azamax $^{\circledR}, 100$; 200 e $\left.300 \mathrm{~mL} .100 \mathrm{~L}^{-1}\right)$, comparada com o tiametoxam (Actara $250 \mathrm{WG}^{\circledR}, 10 \mathrm{~g} .100 \mathrm{~L}^{-1}$ ) do produto 
comercial - pc), lambda-cialotrina (Karate Zeon 50 $\mathrm{CS}^{\circledR}, 80 \mathrm{~mL}^{1} 100 \mathrm{~L}^{-1}$ ) e um tratamento-controle (água). Antes da pulverização dos tratamentos, foi realizada a contagem prévia do número de pulgões (ninfas e adultos) por folha trifoliolada. Os inseticidas foram aplicados molhando totalmente a planta até o ponto de escorrimento, com auxílio de um pulverizador costal manual (Jacto PJH), com capacidade de 20 litros, equipado com bico-leque (Teejet XR11008VS), num volume de calda de 800 L.ha $^{-1}$.

O delineamento experimental foi o inteiramente casualizado, com cinco repetições, sendo cada uma composta por quatro plantas de morangueiro, totalizando 20 plantas por tratamento. Como testemunha, foram utilizadas plantas pulverizadas somente com água.

Aos sete dias após a primeira pulverização (DAPP), a azadiractina foi reaplicada nas mesmas dosagens. Não houve reaplicação dos inseticidas tiametoxam e lambda-cialotrina devido à elevada mortalidade decorrente da primeira pulverização.

A variável resposta avaliada foi o número de insetos sobreviventes (ninfas e adultos) por folha trifoliolada, realizada 24 horas após a primeira aplicação, e aos três, cinco, sete, dez e 15 DAPP. No momento das avaliações, também foi realizada a contagem de ninfas, estimando-se a fecundidade das fêmeas. A avaliação foi realizada com auxílio de uma lupa manual (20 vezes de aumento), considerando-se mortos os pulgões que não apresentavam movimentos perceptíveis ao toque de um pincel de ponta fina.

\section{Avaliação da persistência biológica de in- seticidas para o controle de $\boldsymbol{C}$. fragaefolli}

Para avaliar a persistência biológica dos inseticidas sobre C. fragaefolli, os tratamentos azadiractina $\left(\right.$ Azamax $^{\circledR}, 100 ; 200$ e $300 \mathrm{~mL} .100 \mathrm{~L}^{-1}$ ), tiametoxam (Actara $250 \mathrm{WG}^{\circledR}, 10$ g. $100 \mathrm{~L}^{-1}$ ) e lambda-cialotrina (Karate Zeon $50 \mathrm{CS}^{\circledR}, 80 \mathrm{~mL} .100 \mathrm{~L}^{-1}$ ) foram comparados com um tratamento-Testemunha (somente água). Os inseticidas foram pulverizados uma vez sobre 20 plantas de morangueiro da cultivar Aromas não infestadas com pulgões, cultivadas em casa de vegetação.

Após 24 horas e aos 03; 05; 07; 10; 15; 21 e 28 dias após a pulverização (DAP), foi retirado um folíolo da região mediana de cada planta, os quais foram levados ao laboratório e acondicionados sob uma camada Ágar-água (3\%) em placas de Petri ( $1,3 \mathrm{~cm}$ altura x $6,5 \mathrm{~cm}$ de diâmetro), colocando-se um folíolo por placa.

O delineamento experimental foi inteiramente casualizado, com dez repetições por tratamento. Cada repetição (placa) foi constituída por dez adultos de
C. fragaefolli com, aproximadamente, dez dias de idade, totalizando 100 insetos por tratamento. Os insetos foram transferidos com auxílio de um pincel, e as placas contendo os pulgões foram acondicionadas em câmara climatizada com temperatura de $25 \pm 1^{\circ} \mathrm{C}$, umidade relativa de $70 \pm 10 \%$ e fotofase de 12 horas.

A avaliação da mortalidade foi realizada 24 horas após a infestação dos folíolos, sendo considerado indivíduo morto aquele que não apresentou movimentos perceptíveis ao toque de pincel fino sob estereomicroscópio (20 vezes de aumento).

\section{Análise estatística}

Os dados obtidos no experimento de avaliação do efeito da azadiractina e da persistência biológica dos inseticidas sobre $C$. fragaefolli foram testados quanto à normalidade, utilizando o teste de Shapiro e Wilk (1965), e de homogeneidade de variância dos erros por Hartley (1950). A eficiência de controle dos inseticidas foi calculada pela fórmula de Henderson e Tilton (1955), devido à desuniformidade na infestação prévia dos tratamentos. Para discriminação dos tratamentos, as médias foram comparadas pelo teste de Tukey $(\mathrm{P} \leq 0,05)$, utilizando o software SAS $^{\circledR}$ (SAS INSTITUTE, 2000).

\section{RESULTADOS E DISCUSSÃO}

\section{Efeito de inseticidas para o controle de $C$. fragaefolli}

Na contagem prévia (CP), o número médio de pulgões por folha foi de 25 a 100 insetos (adultos e ninfas) demonstrando diferenças no nível de infestação nas plantas (Tabela 1). A variação de infestação foi atribuída à dificuldade do inseto em colonizar uniformemente as plantas a partir da metodologia empregada.

No primeiro dia após a primeira pulverização (DAPP), a azadiractina $\left(100 ; 200 ; 300 \mathrm{~mL} \cdot 100 \mathrm{~L}^{-1}\right.$ do pc) reduziu a população do pulgão em $9,2 \%, 26,9 \%$ e $50,1 \%$, respectivamente, diferindo dos inseticidas tiametoxam e lambda-cialotrina que reduziram a infestação em $82,8 \%$ e 90,2\%, respectivamente, quando comparados com o tratamento-testemunha (Tabela 1). Após 24 horas da pulverização, foi verificado que os inseticidas sintéticos proporcionaram maior mortalidade que a azadiractina, independentemente da concentração empregada. O elevado efeito de choque dos inseticidas sintéticos tem justificado a preferência por estes grupos químicos por parte dos produtores.

Lowery e Isman (1993) verificaram mortalidade de 55,2\% de $C$. fragaefolli com única pulverização de óleo de semente de nim $\left(\operatorname{NOS}^{\circledR} 1,0 \%\right)$ em 
cultivo comercial de morangueiro da cultivar Toten. Entretanto, quando o mesmo produto foi aplicado na mesma concentração sobre a população de $M$. persicae em pepino, a redução da população foi de $80,9 \%$. De acordo com Schmetterer (1990), além da praga-alvo e da incidência de luz (fotodecomposição do produto), as características da planta, tais como pilosidade e taxa fotossintética podem influenciar positiva ou negativamente o efeito da azadiractina.

Aos cinco DAPP, nos tratamentos com azadiractina, foi observado um incremento significativo na mortalidade quando comparado com os valores obtidos na primeira avaliação, resultando numa mortalidade entre $66,7 \%$ e $69 \%$, sem haver diferença significativa entre as concentrações de azadiractina avaliadas. Mesmo com aumento da mortalidade no tratamento com azadiractina, esta foi menor quando comparada com o tiametoxam e lambda-cialotrina que reduziram a população em $99,1 \%$ e $100 \%$, respectivamente (Tabela 1).

$\mathrm{Na}$ avaliação realizada aos sete DAPP, foi observado que, no tratamento com azadiractina, embora tenha ocorrido uma redução na infestação por $C$. fragaefolli nas plantas de morangueiro, entre $68,8 \%$ e $74,5 \%$, a mortalidade não foi considerada satisfatória, quando comparada com os resultados proporcionados pelos inseticidas tiametoxam e lambda-cialotrina, pois ainda se encontravam, em média, de 11 a 35 pulgões por folha. Por esse motivo, foi realizada uma segunda pulverização de azadiractina nas três concentrações $(100 ; 200$ e 300 $\mathrm{mL} .100^{-1}$ ).

A baixa mortalidade observada nos tratamentos com azadiractina após a primeira pulverização indica que o produto não apresenta um efeito de choque quando comparado com os neonicotinoides (tiametoxam) e piretroides (lambda-cialotrina), os quais proporcionaram um elevado controle da praga com única pulverização (Tabela 1). $\mathrm{O}$ controle químico pode ser vantajoso para o sistema de produção convencional, principalmente quando ocorrem elevadas infestações da praga na cultura, necessitando de um controle rápido e eficiente em um curto intervalo de tempo. No entanto, o uso de produtos à base de azadiractina pode ser uma alternativa, sobretudo em situações onde o manejo da praga é associado ao controle biológico natural sobre os insetos remanescentes com base no reduzido efeito do composto sobre inimigos naturais (BERNARDI et al., 2010).

Aos dez DAPP, ou três dias após a segunda pulverização (DASP) da azadiractina, foi constatado que, independentemente da concentração empregada, houve um controle próximo a $90 \%$, equivalendo-se, portanto, aos inseticidas tiametoxam e lambda-cialotrina (Tabela 1).

$\mathrm{Na}$ avaliação final realizada aos 15 DAPP, ou oito DASP, a azadiractina, independentemente da concentração empregada, foi equivalente aos inseticidas tiametoxam e lambda-cialotrina, proporcionando controle superior a 90\% (Tabela 1). Estes resultados corroboram os verificados por $\mathrm{Hu}$ et al. (1998), que obtiveram $100 \%$ de mortalidade de ninfas de segundo instar de M. persicae e Brevicoryne brassicae (Linnaeus, 1778) (Hemíptera: Aphididae) em couve, e por Araujo et al. (2009) no controle de Lipaphis erysimi (Kaltenbach, 1843) (Hemíptera: Aphididae) na mesma cultura, quando aplicado óleo de nim $\left(\right.$ Neemseto $\left.^{\circledR}\right)$ sobre os pulgões.

Observou-se, neste presente trabalho, que a azadiractina afetou a coloração e a mobilidade dos pulgões, deixando as ninfas com coloração escura e pouco móveis quando tocadas, quando comparados com as ninfas do tratamento-testemunha. Além deste efeito, Mordue (Luntz) e Nisbet (2000) atribuem ao nim outros efeitos fisiológicos que interferem no crescimento, metamorfose, reprodução e processos celulares, muito mais consistentes que os de inibição alimentar. Os insetos também podem sofrer alterações no sistema neuroendócrino, que é responsável pela produção de hormônios do crescimento, tendo em vista que a azadiractina atua como regulador de crescimento, causando formação anormal dos adultos (SCHMUTTERER, 1990).

Além do efeito de mortalidade, a azadiractina reduziu a fecundidade de C. fragaefolli em $28 \%$ quando comparado com o tratamento-testemunha (Figura 1). Santos et al. (2004), estudando o efeito de extratos aquosos de pó de sementes de nim sobre Aphis gossypii Glover, 1877 (Hemíptera: Aphididae), verificaram que fêmeas alimentadas com discos de folhas de algodoeiros tratados não geraram descendentes, enquanto as fêmeas não submetidas ao tratamento apresentaram aumento ninfal de 35 vezes. Segundo Schmutterer (1990) e Martínez (2002), substâncias derivadas do nim, uma vez ingeridas pelos artrópodes, provocam esterilidade das células reprodutivas, reduzindo a fertilidade e a fecundidade dos indivíduos.

$\mathrm{O}$ fato de a pulverização ter sido realizada diretamente sobre os insetos (ninfas e adultos) após a infestação indica que, além da ingestão, o contato com os pulgões potencializou o efeito da azadiractina. A ação de contato do composto sobre pulgões foi demonstrada em Aphis craccivora (Hemíptera: Aphididae) na cultura do feijoeiro (STARK; RANGUS, 1994) e sobre a mosca-branca Bemisia tabaci (Gennadius) (Hemíptera: Aleyrodidae) em melão (BLEICHERET al., 2007). 
Segundo Mordue (Luntz) e Nisbet (2000) e Martínez (2002), a pulverização de azadiractina sobre plantas reduz a capacidade de alimentação de insetos sugadores, podendo afetar a habilidade desses em transmitir viroses, assim como causar redução nas concentrações de ecdisônio e do hormônio juvenil na hemolinfa, afetando diretamente a ecdise e a metamorfose dos insetos.

\section{Persistência biológica de inseticidas sobre C. fragaefolli}

Na avaliação realizada um dia após a pulverização (DAP), foi observada mortalidade de aproximadamente $50 \%$ nos tratamentos com azadiractina, nas três concentrações, diferindo dos resultados obtidos nos tratamentos com tiametoxam e lambda-cialotrina que proporcionaram mortalidade de $100 \%$ dos insetos (Figura 2).

Aos três e cinco DAP, observou-se incremento na mortalidade (55\% a $80 \%$ ) dos pulgões em função da concentração de azadiractina empregada (Figura 2). Martínez (2002) verificou que os maiores picos de ingredientes ativos de produtos derivados do nim, que translocam na planta, ocorrem cinco dias após o tratamento, fato similar ao observado neste trabalho.

Aos sete DAP, foi verificado que a azadiractina, em todas as concentrações avaliadas, apresentou redução na atividade biológica, provocando em torno de $65 \%$ de mortalidade dos insetos (Figura 2). Esta redução na mortalidade pode ser atribuída à temperatura e à luz ultravioleta que incidiram sobre as plantas do experimento, resultando na degradação do produto. Segundo Saxena et al. (1984), temperatura, luminosidade e precipitação pluviométrica são os principais fatores que promovem a degradação de compostos derivados de nim nas plantas. Nas avaliações realizadas aos $15 ; 21$ e 28 DAP, houve decréscimo contínuo na mortalidade dos pulgões quando expostos aos tratamentos com azadiractina (Figura 2). Este comportamento reforça a necessidade da reaplicação do produto aos sete dias após a primeira pulverização (pico de atividade biológica) para um controle efetivo de $C$. fragaefolli. Esta consideração também é mencionada por Martínez (2002) que afirma que a concentração de ingrediente ativo de produtos derivados de nim se mantém nas raízes, ramos e folhas das plantas até, no máximo, oito dias após sua aplicação, começando a perder efetividade a partir deste período. Aos 28 DAP, a azadiractina, nas três concentrações avaliadas, resultou em mortalidade inferior a $30 \%$, diferindo dos inseticidas tiametoxam e lambda-cialotrina que foram efetivos no controle da praga com mortalidade de, aproximadamente, $70 \%$ nesta época de avaliação, quando foi concluído o experimento (Figura 2). A azadiractina apresentou atividade biológica, causando mortalidade significativa e crescente de $C$. fragaefolli até os cinco DAP. Esta informação sugere que o inseticida pulverizado somente uma vez não é efetivo para o controle do pulgão. Este comportamento também foi observado por Venzon et al. (2007), que sugeriram aplicações sequenciais de nim para o controle de pulgões na cultura da pimenta. Em relação aos inseticidas sintéticos, tanto o tiametoxam como a lambda-cialotrina controlaram o inseto por $28 \mathrm{DAP}$ (período de condução do experimento). O longo efeito biológico desses dois inseticidas sintéticos sobre o pulgão-verde pode ser considerado vantajoso quando observado o efeito sobre os pulgões. No entanto, maior persistência também pode atuar negativamente sobre a fauna benéfica que constitui os inimigos naturais, resultando no incremento de outras pragas no cultivo, principalmente o ácaro-rajado, devido à toxicidade dos produtos sintéticos sobre os ácaros predadores (N. californicus e P. macropilis) no cultivo do morangueiro (POLETTI et al., 2008).

Com base nesses resultados, verifica-se que a utilização da formulação comercial à base de azadiractina (Azamax ${ }^{\circledR}, 12 \mathrm{~g}$ de ingrediente ativo/ Litro) é uma alternativa ao uso dos inseticidas neonicotinoides e piretroides para o controle do pulgão C. fragaefolli na cultura do morangueiro, tanto para o sistema de cultivo convencional como para o cultivo orgânico de produção da fruta. O produto pode ser aplicado na menor concentração avaliada (100 ml.100L $\mathrm{L}^{-1}$ do pc), devendo-se realizar duas pulverizações, com intervalo de sete dias entre elas para o controle do pulgão do morangueiro. 


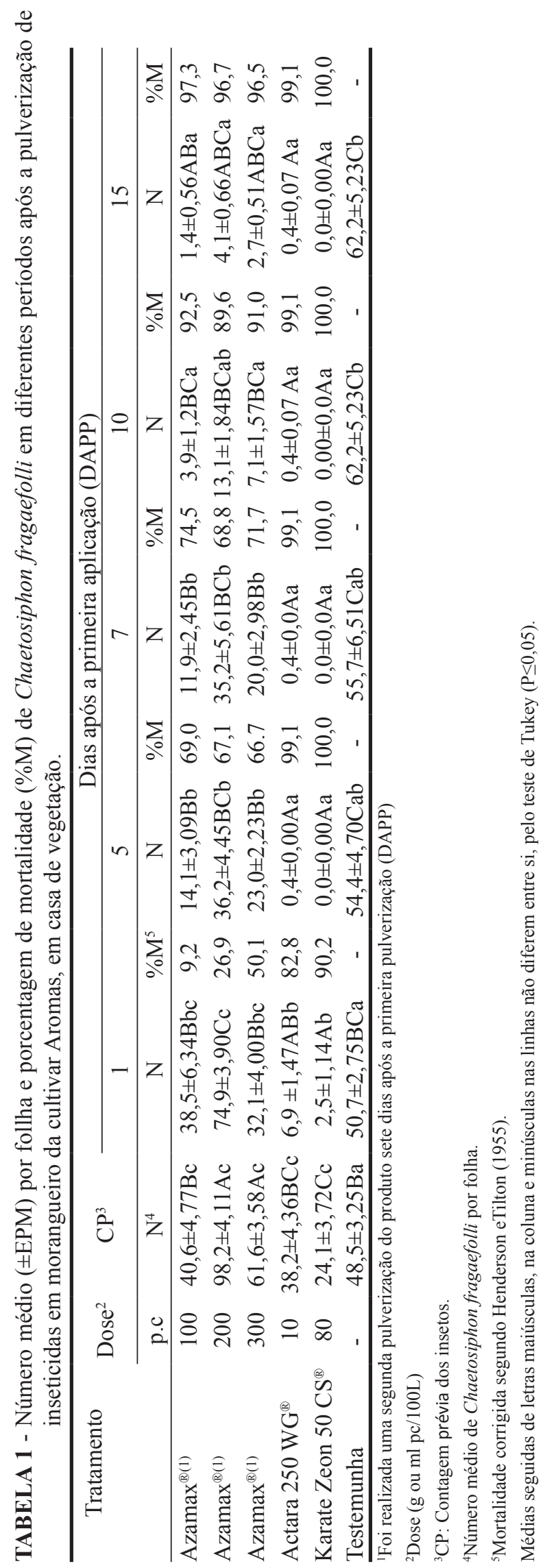




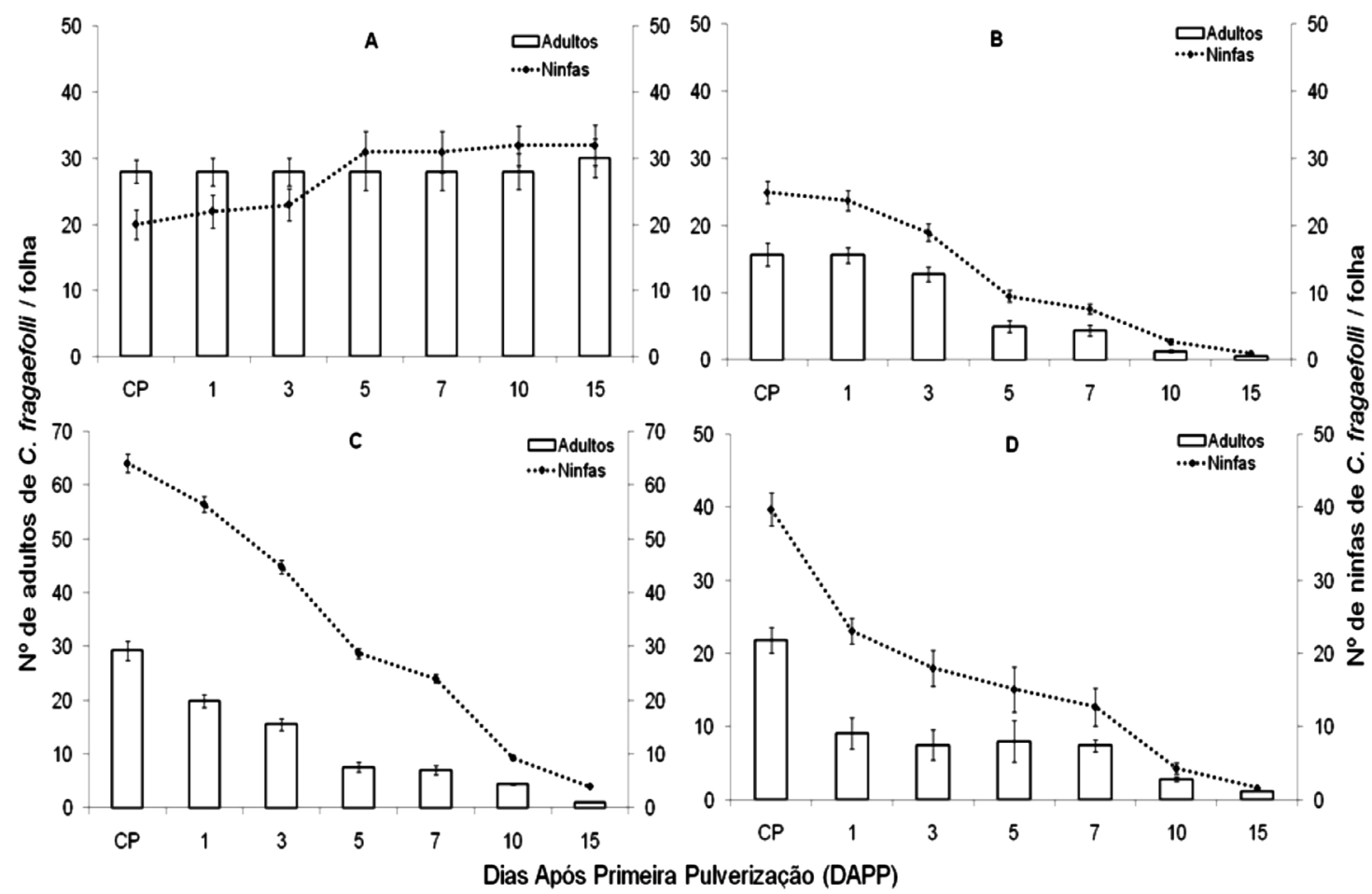

FIGURA 1 - Número médio de adultos e ninfas de Chaetosiphon fragaefolli em plantas de morangueiro da cultivar Aromas, cultivadas em casa de vegetação e pulverizadas com diferentes inseticidas, na contagem prévia (CP), e um, três, cinco, sete e 15 dias após a primeira pulverização (DAPP). (A) Testemunha; (B) Azadiractina (Azamax ${ }^{\circledR} 100$ mL.100L $\mathrm{L}^{-1}$ do pc); (C) Azadiractina (Azamax ${ }^{\circledR}$ $200 \mathrm{~mL} \cdot 100 \mathrm{~L}^{-1}$ do pc); (D) Azadiractina (Azamax ${ }^{\circledR} 300 \mathrm{~mL} \cdot 100 \mathrm{~L}^{-1}$ do pc).

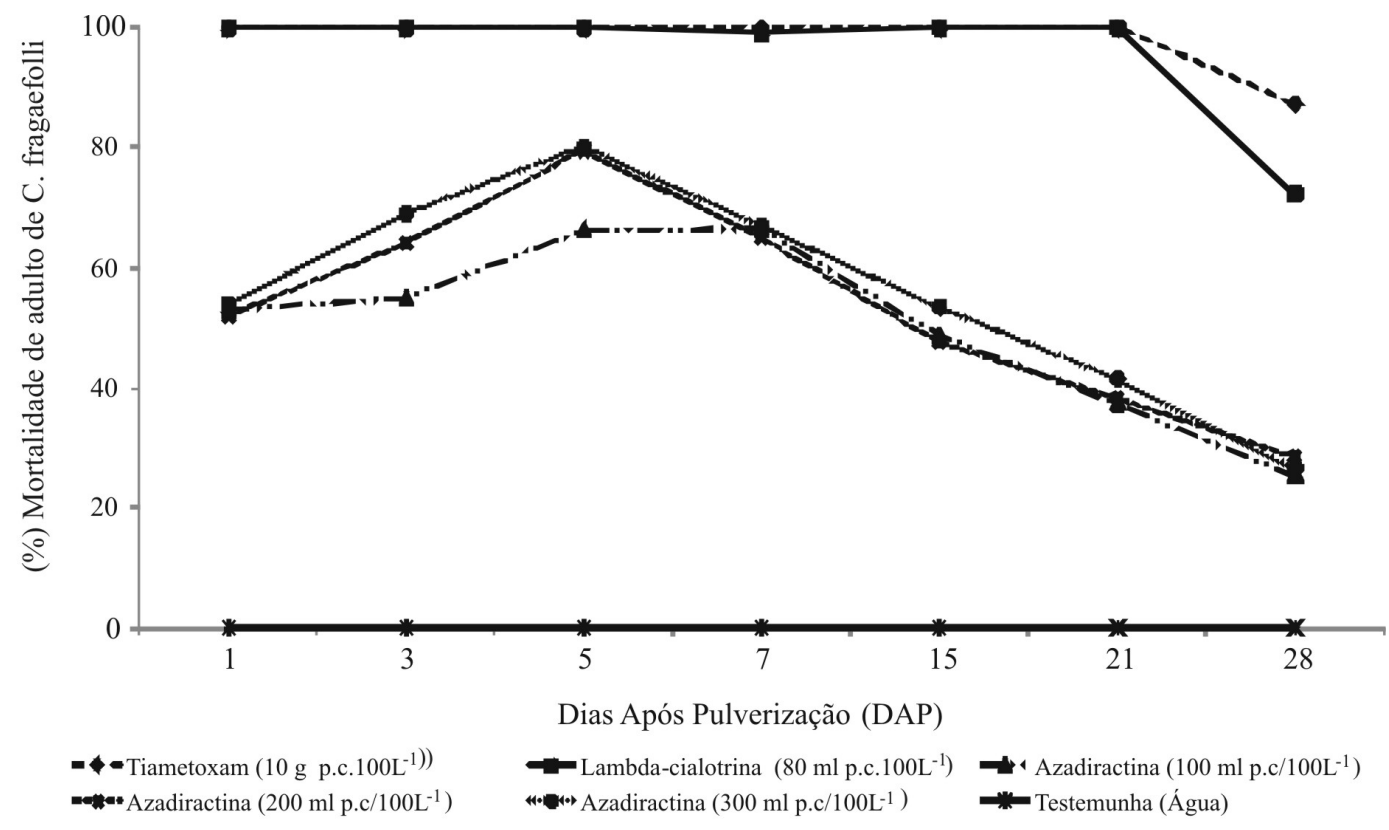

FIGURA 2 - Mortalidade de adultos de Chaetosiphon fragaefolli em diferentes períodos após a pulverização de diferentes inseticidas sobre plantas de morangueiro da cultivar Aromas, cultivadas em casa de vegetação. 


\section{CONCLUSÕES}

1-A azadiractina $\left(100,200,300 \mathrm{ml} \cdot 100 \mathrm{~L}^{-1}\right.$ do pc), pulverizados via foliar são eficientes no controle de Chaetosiphon fragaefolli na cultura do morangueiro após duas pulverizações com intervalo de sete dias, utilizando um volume de calda de 800 L.ha $^{-1}$.

2-A azadiractina $\left(100,200,300 \mathrm{ml} .100 \mathrm{~L}^{-1}\right.$ do $\mathrm{pc}$ ), pulverizados via foliar apresentam uma persistência biológica de sete dias na cultura do morangueiro, necessitando ser reaplicado após esse intervalo de tempo.

3-Os inseticidas tiametoxam $\left(10 \mathrm{~g} \cdot 100 \mathrm{~L}^{-1}\right.$ do pc) e lambda-cialotrina ( $80 \mathrm{ml} \cdot 100^{-1}$ do $\left.\mathrm{pc}\right)$, pulverizados via foliar, são eficientes no controle de Chaetosiphon fragaefolli na cultura do morangueiro.

\section{REFERÊNCIAS}

AGROFIT. Site Ministério da Agricultura e Pecuária. Disponível em: $<$ http:/www.agricultura.gov. br/>. Acesso em: 5 dez. 2011.

ARAUJO, J. M. Jr. de.; MARQUES, J.E.; OLIVEIRA, J.V. de. Potencial de isolados de Metarhizium anisopliaee e Beauveria bassianae do óleo de nim no controle do pulgão Lipaphiserysimi(Kalt.) (Hemiptera: Aphididae). Neotropical Entomology, Londrina, v. 38, n. 4 , p. $520-525,2009$.

BERNANDI, D.; BOTTON, M.; CUNHA, U.S.da; NAVA, D.E.; GARCIA, M.S. Bioecologia, monitoramento e controle do ácaro-rajado com o emprego da azadiractina e ácaros predadores na cultura do morangueiro. Bento Gonçalves: Centro Nacional de Pesquisa Uva e Vinho, 2010. 16p. (Circular Técnica, 83).

BLEICHERET, E.; GONÇALVES, M.E.C.; SILVA, L. Efeito de derivados de nim aplicados por pulverização sobre a mosca-branca em meloeiro. Horticultura Brasileira, Brasília, v.25, n.1, p.110-113, 2007.

BOTTON, M.; BERNARDI, D.; NAVA, D.E.; CUNHA, U.S. da; GARCIA, M.S. Manejo de pragas na cultura do morangueiro. In: SIMPÓSIO NACIONAL DO MORANGO, 5.; ENCONTRO SOBRE PEQUENAS FRUTAS E FRUTAS NATIVAS DO MERCOSUL, 4., 2010, Pelotas. Resumo... p.23-29.
CÉDOLA, C.; GRECO, N. Presence of the aphid Chaetosiphon fragaefolii on strawberry in Argentina. Journal of Insect Science, Wallingford, v.9, n. 10, p.1-9, 2010

COSTA, C.L.; EASTOP, V.F.; BLACKMAN, R.L. Brazilian Aphidoidea: I. Key to families, subfamilies and account of the phylloxeridae. Pesquisa Agropecuária Brasileira, Brasília, v.28, n.2, p.197-215, 1993.

HARTLEY, H.O. The use of range in analysis of variance. Biometrika, London, v.37, p.271-280, 1950.

HENDERSON, C.F.; TILTON, E.W. Tests with acaricides against the brown wheat mite. Journal of Economic Entomology, Lanham, v.48, n. n/s p.157-161, 1955.

HU, M.; KLOCKE, J.A.; BARNBY, M.A.; CHIU, S.; ZHAO, S.; HU, M.Y. Systemic insecticidal action of azadirachtin, neem seed and chinaberry seed extracts applied as soil drenches to potted plants. Entomologia Sinica, Shensi, v.5, n.2, p.177-188, 1998.

ISMAN, M. B. Botanical insecticides deterrents and repellents in modern agriculture and an increasingly regulated world. Annual Review of Entomology, Stanford, v.51, n.s/n, p.45-66. 2006.

LOWERY, D.T.; ISMAN, M.B. Antifeedant activity of extracts from Neem, Azadirachta indica, to Strawberry aphid Chaetosiphon fragaefolii. Journal of Chemical Ecology, New York, n.19, p.17611773, 1993.

MARTINEZ, S.S. O nim - Azadirachta indica - natureza, usos múltiplos, produção. Londrina: IAPAR, 2002. 142 p.

MELLOW, F.C.; FRAZIER, N.W. Strawberry crinkle. In: FRAZER, N.W. Virus disease of small fruits and grapevines. Berkerley: University of California Berkeley, Division of Plant Industry, 1970. p.18-23.

MORDUE (LUNTZ), A.J; NISBET, A.J. Azadirachtin from the neem tree Azadirachta indica: its action against insects. Anais da Sociedade Entomológica do Brasil, Piracicaba, v.29, n.4, p.615632,2000 . 
POletTi, M.; COLletTe, L. de P.; OMOTO, C. Compatibilidade de agrotóxicos com os ácaros predadores Neoseiulus californicus (McGregor) e Phytoseiulus macropilis (Banks) (Acari: Phytoseiidae). BioAssay, Piracicaba, v.3, n.3, p.14, 2008.

RONDON, S.; CANTCLIFFE, D. Chaetosiphon fragaefolii (Homoptera: Aphididae): A potential new pest in Florida? Florida Entomologist, Gainesville, v.4, n.87, p.612-614, 2004.

SALLES, L.A. Pragas do morangueiro In: EMBRAPA CLIMA TEMPERADO. Sistema de produção do morango. Pelotas, 2005. Disponível em: $<$ http://sistemasdeproducao.cnptia.embrapa.br/ FontesHTML/Morango/Sistema ProducaoMorango/ cap07.htm>. Acesso em: 22 nov. 2010.

SANTOS, T.M.; COSTA, N.P.; BOIÇA JÚNIOR, A. L. Efeito de extrato de nim sobre o pulgão-doalgodoeiro. Pesquisa Agropecuária Brasileira, Brasília, v.39, n.11, p.1071-1076, 2004.

SAS INSTITUTE. Statistical analysis system: getting started with the SAS learning. Cary, 2000. 81p.
SAXENA, R.C.; JUSTO, H.D.; EPINO, P.B. Evaluation and utilization of neem cake against the rice brown plant hopper, Nilaparvata lugens(Homoptera: Delphacidae). Journal of Economic Entomology, Manasha, v.77, n.s/n, p.502-507, 1984.

SCHMUTTERER, H. Properties and potential of natural pesticide from the neem tree, Azadirachta indica. Annual Review of Entomology, Stanford, v.35, p.271-297, 1990.

SHAPIRO S.S.; WILK, M.B. An analysis of variance test for normality (complete samples). Bometrika, London, v.52, n.3-4, p.591-611, 1965.

STARK J.D.; RANGUS T.M. Lethal and sublethal effects of the neem insecticide formulation, 'Margosan- ${ }^{\circledR}$, on the pea aphid. Pesticide Science, Oxford, v.41, n.1, p.155-160, 1994.

VENZON, M.; ROSADO, M. C.; PALLINI, A.; FIALHO, A.; PEREIRA, C. J. Toxicidade letal e sub-letal do nim sobre o pulgão-verde e seu predador Eriopis connexa. Pesquisa Agropecuária Brasileira, Piracicaba, v.42, n.5, p.627-631, 2007. 